\title{
Analisis Leverage, Firm Size, Deviden Payout terhadap Stock Price Volatility Pada Perusahaan LQ45 di BEI Tahun 2015-2019
}

\author{
Arna Suryani \\ Fakultas Ekonomi Universitas Batanghari \\ Correspondence email: arna_halim@yahoo.co.id
}

\begin{abstract}
Abstrak. Penelitian ini menguji dan menganalisis pengaruh Leverage, Firm Size, Deviden Payout terhadap Stock Price Volatility. Penelitian ini dilakukan pada perusahaan yang terdaftar dalam indeks LQ45 di Bursa Efek Indonesia tahun 2015-2019. Sampel dipilih berdasarkan purposive sampling sehingga terpilih sebanyak 27 perusahaan sampel. Alat analisis digunakan regresi linear berganda dengan uji asumsi klasik dan uji hipotesis. Berdasarkan hasil analisis menunjukkan bahwa Leverage berpengaruh positif terhadap Stock Price Volatility, sedangkan Firm Size, Deviden Payout berpengaruh negatif terhadap Stock Price Volatility. Penelitian ini dapat membuktikan bahwa tindakan yang di ambil manajemen perusahaan dapat dilihat dari bagaimana perusahaan seharusnya memposisikan asset dan kewajiban perusahaan maupun pembagian deviden. Penelitian ini diharapkan dapat memberikan kontribusi positif bagi semua pihak khususnya pihak investor dalam berinvestasi di pasar modal tetap memperhatikan tingkat leverage, firm size dan dividend payout ratio perusahaan yang akan diinvestasikan.
\end{abstract}

Kata kunci: Leverage, Firm Size, Deviden Payout, Stock Price Volatility

\begin{abstract}
This study examines and analyzes the effect of Leverage, Firm Size, Dividend Payout on Stock Price Volatility. This research was conducted on companies listed in the LQ45 index on the Indonesia Stock Exchange in 2015-2019. The sample was selected based on purposive sampling so that 27 sample companies were selected. Multiple linear regression analysis tool with classical assumption test and hypothesis testing. The results based on the analysis show that Leverage has a positive effect on Stock Price Volatility, while Company Size, Dividend Payout has a negative effect on Stock Price Volatility. This research can prove that the actions taken from the company's management can be seen from how the company should position the company's assets and liabilities as well as the distribution of dividends. This research is expected to make a positive contribution to all parties, especially investors in investing in the capital market while still paying attention to the level of leverage, company size and dividend payout ratio of the company to be invested.
\end{abstract}

Keywords: Leverage, Firm Size, Dividend Payout, Stock Price Volatility

\section{PENDAHULUAN}

Berinvestasi dalam saham memiliki resiko yang besar namun juga mempunyai keuntungan yang menggiurkan (high risk high return), sehingga investasi di pasar modal semakin berkembang di Indonesia. Salah satu indikator yang menunjukkan perkembangan bursa efek adalah kapitalisasi pasar. Kapitalisasi pasar menunjukkan nilai efek yang tercatat di bursa saham. Pasar modal mempunyai peran yang sangat penting bagi perusahaan maupun inverstor. Jika dilihat dari segi investor dapat memberikan kesempatan kepada investor dalam mendapatkan keuntungan berupa deviden dan capital gain dan bagi perusahaan dapat memperoleh modal dalam jangka panjang untuk pengembangan usaha untuk memenuhi keinginan para pemegang saham dengan kebijakan deviden dan stabilitas harga sekuritas yang normal.

Terdapat hubungan antara hutang jangka panjang dengan harga saham yang signifikan dan berhubungan negatif.Artinya adalah semakin tinggi hutang jangka panjang maka semakin rendah harga saham perusahaan Baghbani dan Bahreini (2013). perusahaan dengan hutang jangka panjang yang lebih tinggi akan lebih tinggi juga kemungkinan untuk kehilangan proyek dimasa depan karena dalam beberapa kondisi, hasil akhir setelah penurunan biaya akan lebih kecil daripada jumlah yang pemegang saham investasikan Baghbani dan Bahreini (2013). Pengurangan dalam investasi akan mengurangi nilai perusahaan. Oleh karena itu peningkatan hutang jangka panjang akan menyebabkan penurunan harga saham dan faktor-faktor lainnya akan mengikuti.

Terdapat hubungan negatif antara hutang jangka panjang dan stock price volatility. semakin tinggi leverage suatu perusahaan maka semakin rendah volatilitas harga saham perusahaan tersebut,sehingga dengan peningkatan leverage merupakan sinyal bahwa perusahaan berusaha untuk berinvestasi sehingga merupakan kesempatan perusahaan untuk bertumbuh dan hal ini menjadi peluang bagi para investor dan berujung pada harga saham yang stabil Shah dan Noreen (2016).

Dimana harga saham pada perusahaan yang besar lebih stabil daripada harga saham pada perusahaan kecil karena pada perusahaan besar cenderung lebih di versivikasi. bahwa firm size menyebabkan dampak yang paling besar pada stock price volatility diantara variabelvariabel kontrol lainnya sehingga stock price volatility mempunyai asosiasi terbalik dengan firm size. Terdapat hubungan negatif antara firm size dan stock price volatility.Sehingga hal ini berarti semakin besar firm size 
maka lebih rendah terjadinya stock price volatility Shah dan Noreen (2016).

Adanya hubungan signifikan negatif dividend payout ratio dengan stock price volatility. Hal ini berarti bahwa semakin besar dividend payout ratio maka semakin kecil stock price volatility dan begitu juga sebaliknya Hal ini dikarenakan perusahaan yang kebijaan dividennya pasti akan menekan risiko perusahaan. Dengan adanya peningkatan dividen maka akan meningkatkan kepercayaan investor, hal ini menyebabkan cash flow terdiskon pada tingkat pengembalian yang rendah dan menyebabkan kenaikan harga saham sedangkan jika mengurangi dividen akan memperbesar ketidakpastian pada investor sehingga menyebabkan harga saham perusahaan jatuh. jika sebuah perusahaan memiliki record yang kuat dalam membayar dividen (bahkan mungkin telah mungkin telah meningkatkan dividennya selama bertahun-tahun), maka jika terjadi sebaliknya secara tiba-tiba biasanya kebijakan dividen akan merugikan harga saham setidaknya dalam jangka pendek (meskipun secara teoritis, dana tersebut akan diinvestasikan kembali dalam bentuk laba ditahan dan pada akhirnya akan menyebabkan harga saham yang lebih tinggi). Sangatlah penting bahwa perusahaan memberikan indikasi yang jelas dari kebijakan dividen sehingga dividen dapat diprediksi oleh investor (Griffin:2010). Hasil penelitian dari Shah dan Noreen (2016) juga menyatakan bahwa terdapatnya hubungan signifikan positif antara kebijakan dividen dan stock price volatility. Sehingga semakin tinggi dividend payout maka lebih sedikit terjadinya stock price volatility.

Investor secara alamiah akan menghindari risiko, sehingga kenaikan atau penurunan pada harga saham (Stock Price Volatility), Volatilitas yang lebih besar menunjukkan kemungkinan terjadinya keuntungan atau kerugian yang lebih tinggi sehingga dapat berubah sewaktu-waktu dan perubahannya sulit untuk diprediksi. Hal ini menyebabkan stock price volatility penting perusahaan dan bagi investor karena investasi mereka menjadi penting dalam mengukur level risiko yang akan mereka hadapi. Beberapa penelitian yang telah dilakukan menunjukkan beberapa teori yang berkaitan pada pengambilan keputusan investor yang berujung pada stock price volatility.

Volatilitas adalah tingkat perubahan harga dari sekuritas selama periode waktu tertentu dan akibatnya jika semakin besar volatilitas maka semakin besar risiko keuntungan atau kerugian Profilet dan Bacon (2013). Stock price volatility telah menjadi perhatian banyak peneliti dikarenakan volatilitas return saham mewakili variabilitas perubahan harga saham dapat dianggap sebagai ukuran risiko yang di hadapi oleh investor. Stock price volatility cenderung naik ketika informasi baru dirilis ke pasar, namun seberapa tingginya ditentukan dengan relevansi informasi terbaru tersebut serta seberapa besar berita itu mengejutkan para investor Ilaboya dan Aggreh (2013).

Bila kenaikan atau penurunan saham terjadi terusmenerus selama beberapa hari, maka akan diikuti dengan arus balik, karena overreaction atau mispriced overreaction terjadi akibat investor terlalu optimis atau pesimis dalam menanggapi suatu peristiwa yang diperkirakan berpengaruh terhadap kinerja perusahaan di masa datang. Terlalu optimis atau pesimistis akan mempercepat kenaikan atau penurunan harga saham sehingga ada unsur mispriced, akibatnya akan terjadi arus balik untuk mengkoreksi mispriced tersebut. Oleh karena itu, investor berhati-hati terhadap pergerakan harga saham yang terlalu cepat naik atau terlalu cepat turun dengan tajam atau istilahnya terjadi stock price volatility. Kemampuan investor untuk memprediksi ada tidak nya stock price volatility akan mempengaruhi return yang akan di dapat oleh investor. Adanya volatilitas akan menyebabkan risiko dan ketidak pastian yang dihadapi investor semakin besar (Kartika.2010).

\section{Kajian Literatur Laverage}

Leverage adalah suatu tingkat kemampuan perusahaan dalam menggunakan aktiva dan atau dana yang mempunyai beban tetap (hutang atau saham istimewa) dalam rangka mewujudkan tujuan perusahaan untuk memaksimisasi kekayaan pemilik perusahaan. Leverage adalah penggunaan aktiva dan sumber dana oleh perusahaan yang memiliki biaya tetap (beban tetap) berarti sumber dana yang berasal dari pinjaman karena memiliki bunga sebagai beban tetap dengan maksud agar meningkatkan keuntungan potensial pemegang saham Sjahrial (2009).

Leverage adalah kemampuan perusahaan untuk mengelola dana yang mempunyai beban tetap untuk memaksimalkan tujuan perusahaan (meningkatkan keuntungan perusahaan). Perusahaan yang memiliki biaya operasi tetap atau biaya modal tetap, maka perusahaan tersebut menggunakan leverage. Penggunaan leverage dapat menimbulkan beban dan risiko bagi perusahaan, apalagi jika keadaan perusahaan sedang memburuk. Di samping perusahaan harus membayar beban bunga yang semakin membesar, kemungkinan perusahaan mendapat penalti dari pihak ketiga pun bisa terjadi.

\section{Firm Size}

Firm Size merupakan ukuran yang dipakai untuk mencerminkan besar kecilnya perusahaan yang didasarkan kepada total aset perusahaan Suwito dan Herawaty (2005). Besar kecilnya usaha tersebut ditinjau dari lapangan usaha yang dijalanakan. Penentuan skala besar kecilnya perusahaan dapat ditentukan berdasarkan total penjualan, total asset, rata-rata tingkat penjualan (Seftianne, 2011). Perusahaan yang berukuran besar mempunyai berbagai kelebihan dibanding perusahaan 
berukuran kecil. Kelebihan tersebut adalah ukuran perusahaan dapat menentukan tingkat kemudahan perusahaan memperoleh dana dari pasar modal, ukuran perusahaan menentukan kekuatan tawar-menawar (Bargaining Power) dalam kontrak keuangan kemudian ada kemungkinan pengaruh skala dalam biaya dan return membuat perusahaan yang lebih besar dapat memperoleh lebih banyak laba (Sawir, 2004) dalam (Oktavianti, 2015).

\section{Devidend Payout}

Dividen adalah bagian laba usaha yang diperoleh perusahaan dan diberikan oleh perusahaan kepada pemegang sahamnya sebagai imbalan atas kesediaan mereka menanamkan hartanya dalam perusahaan Rudianto (2012). Bagian dari keuntungan yang dibagikan kepada pemegang saham yang dapat berupa dividen tunai atau dividen saham Gumanty (2013). Dividen merupakan suatu pembagian laba dari suatu usaha yang diberikan kepada pemegang saham dimana laba tersebut dapat berupa yaitu dividen tunai adalah bagian laba usaha yang dibagikan kepada pemegang saham dalam bentuk uang tunai. Sebelum dividen dibagikan, perusahaan harus mempertimbangkan ketersediaan dana untuk membayar dividen. Jika perusahaan memilih untuk membagikan dividen tunai itu berarti pada saat dividen akan dibagikan kepada pemegang saham perusahaan memiliki uang tunai dalam jumlah yang cukup atau dividen saham yang dapat memaksimumkan nilai perusahaan disamping keputusan investasi dan struktur modal. Perusahaan yang mempunyai tingkat Devidend Payout yang rendah dianggap lebih bernilai dikarenakan berpotensi mengalami pertumbuhan. Akan tetapi pada waktu yang bersamaan, perusahaan yang sedang mengalami petumbuhan tentunya memiliki tingkat ketidakpastian (risiko) yang lebih besar mengenai aliran kas masa depan dari proyek-proyek investasi baru sebagai perbandingan tingkat pengembalian yang sudah ditempatkan pada aktiva. Hal ini membuat perusahaan lebih berisiko untuk dilakukan investasi. Oleh karena itu, perusahaan dengan tingkat dividen yang rendah akan membuat pergerakan harga sahamnya tidak stabil

\section{Stock Price Volatility}

Volatilitas adalah tingkat perubahan harga dari sekuritas selama periode waktu tertentu dan akibat nya jika semakin besar volatilitas maka semakin besar risiko keuntungan atau kerugian Profilet dan Bacon (2013), Jika saham diberi label sebagai volatile. Dengan demikian, banyak investor yang lebih memilih sahamsaham yang lebih dapat di prediksi karena mempunyai risiko yang lebih kecil. Volatilitas Harga Saham adalah besaran perubahan harga yang menunjukan fluktuasi pasar dalam satu periode tertentu. Stock price volatility cenderung naik ketika informasi baru saja dirilis ke pasar, namun seberapa tinggi ditentukan dengan relevansi informasi terbaru tersebut serta seberapa besar berita itu mengejutkan para investor (Ilaboya dan Aggreh, 2013).

Hipotesis pada penelitian ini adalah:

$\mathrm{H} 1$ : Terdapat pengaruh leverage terhadap stock price volatility pada perusahaan yang terdaftar di BEI tahun 2015-2019.

$\mathrm{H} 2$ : Terdapat pengaruh firm size terhadap stock price volatility pada perusahaan yang terdaftar di BEI tahun 2015-2019.

H3 : Terdapat pengaruh dari dividend payout terhadap stock price volatility pada perusahaan yang terdaftar di BEI tahun 2015-2019

\section{METODE}

Penelitian ini merupakan penelitian deskriptif kuantitatif, Jenis data yang digunakan dalam penelitian ini adalah data sekunder di peroleh dari berupa laporan keuangan perusahaan LQ45 periode 2015-2019. Sampel dipilih berdasarkan purposive sampling sebanyak 27 perusahaan dengan kriteria tertentu. Alat analisis digunakan regresi linear berganda dengan uji asumsi klasik dan uji hipotesis.operasional variabel dapat dilihat pada tabel 1 berikut.

Tabel 1. Operasional Variabel



Sumber: olah data (2021)

\section{HASIL DAN PEMBAHASAN}

Hasil uji asumsi klasik data terdistribusi normal, tidak terjadi multikolinieritas, tidak terjadi auto korelasi dan tidak terjadi heteroskedastisitas. Secara bersamasama leverage, firm size dan devidend payout berpengaruh terhadap stock price volatility sebesar $14,8 \%$ dan tidak signifikan.

Tabel 2. Koefisien Dertiminasi

\begin{tabular}{|l|l|r|r|c|}
\hline Model & R & R Square & Adjusted R Square & Sig. \\
\hline 1 & $.148^{\mathrm{a}}$ &, 022 &,- 001 & $.407^{\mathrm{b}}$ \\
\hline
\end{tabular}

Sumber: olah data SPPS 2021

Untuk mengetahui pengaruh signifikansi variabel penjelas terhadap variabel terkait digunakan Uji t dengan hasil pada tabel 3 berikut. 
Tabel 3. ANOVA ${ }^{\mathrm{a}}$

\begin{tabular}{|c|c|c|c|c|c|}
\hline \multirow[b]{2}{*}{ Model } & \multicolumn{2}{|c|}{$\begin{array}{l}\text { Unstandardized } \\
\text { Coefficients }\end{array}$} & \multirow{2}{*}{ 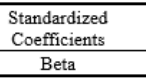 } & & \multirow[b]{2}{*}{ Sig. } \\
\hline & B & Std. Error & & & \\
\hline $\begin{array}{ll}1 & \text { (Constant) }\end{array}$ & 9226,185 & 4371,585 & & 2,110 & ,037 \\
\hline $\mathrm{x} 1$ & ,016 & , 018 & ,119 & , 年999 & , 370 \\
\hline $\mathrm{x}_{2}$ & $-2,271$ & 2,562 &,- 118 & -887 & 377 \\
\hline $\mathrm{x} 3$ & $-3,856$ & 2,731 &, 125 & $-1,412$ & , 160 \\
\hline
\end{tabular}

Sumber: olah data SPPS 2021

Besarnya pengaruh Leverage terhadap stock price volatility sebesar 0,016 dengan tingkat signifikan 0,37 lebih besar $\alpha 0,05$. Hasil ini menunjukkan bahwa leverage berpengaruh tidak signifikan terhadap stock price volatility, berdasarkan hasil ini maka $\mathrm{H}_{1}$ ditolak. Ini menunjukkan bahwa peningkatan leverage merupakan sinyal perusahaan untuk berinvestasi sehingga ada kesempatan perusahaan untuk bertumbuh sehingga menjadi peluang bagi para investor dan berujung pada harga saham yang stabil. Hasil penelitian ini mendukung penelitian (Husainey, Mgbame,dan Mgbame, 2010) menyatakan bahwa hutang jangka panjang memiliki hubungan positif yang signifikan dengan volatilitas harga, yang dapat dikatakan bahwa semakin besar hutang jangka panjang perusahaan maka semakin besar volatilitas harga. Karena peningkatan hutang juga meningkatkan risiko yang dihadapi perusahaan yang disebabkan karena adanya kemungkinan perusahaan tidak dapat membayar hutang dimasa depan jika tingkat hutangnya semakin tinggi.

Besarnya pengaruh Firm size terhadap stock price volatility sebesar negatif 2,271 dengan tingkat signifikan 0,37 lebih besar $\alpha 0,05$. Hasil ini menunjukkan bahwa firm size berpengaruh negatif namun tidak signifikan terhadap stock price volatility, sehingga hipotesis $\left(\mathrm{H}_{2}\right)$ ditolak. Hasil penelitian ini mendukung penelitian Shah dan Noreen (2016) yang menyatakan bahwa terdapatnya hubungan negatif antara firm size dan stock price volatility. penelitian ini mengkonfirmasikan bahwa semakin besar firm size maka lebih rendah terjadinya stock price volatility dimana harga saham pada perusahaan yang besar lebih stabil daripada harga saham pada perusahaan kecil karena pada perusahaan besar cenderung lebih di versivikasi.

Besarnya pengaruh Deviden Payout terhadap stock price volatility sebesar negatif 3,856 dengan tingkat signifikan 0,16 lebih besar dari $\alpha 0,05$. Hasil ini menunjukkan bahwa deviden payout berpengaruh tidak signifikan terhadap stock price volatility, berdasarkan hasil ini maka Hipotesis $\left(\mathrm{H}_{3}\right)$ di tolak. Hasil penelitian ini mendukung penelitian Hashemijoo, Ardekani,dan Younesi (2012) yang menyatakan bahwa adanya hubungan signifikan negatif dividend payout ratio dengan stock price volatility. Hal ini berarti bahwa semakin besar dividend payout ratio maka semakin kecil stock price volatility dan begitu juga sebaliknya, dikarenakan perusahaan yang kebijaan dividennya pasti akan menekan risiko perusahaan. Dan penelitian yang dilakukan oleh Dewi \& Paramita (2019) menyatakan bahwa besarnya jumlah dividen yang dibagi menandakan rendahnya risiko investasi yang dihadapi, dengan begitu banyak investor yang akan mempertahankan sahamnya, sehingga volatilitas harga saham akan menurun

\section{SIMPULAN}

Hasil penelitian ini dapat disimpulkan bahwa leverage, firm size dan devidend payout berpengaruh tidak signifikan terhadap stock price volatility. Hasil penelitian ini juga membuktikan bahwa variabel leverage $\left(\mathrm{X}_{1}\right)$ berpengaruh positif sebesar 0,016 tidak signifikan terhadap stock price volatility, ini menunjukkan bahwa peningkatan leverage merupakan sinyal perusahaan untuk berinvestasi sehingga ada kesempatan perusahaan untuk bertumbuh sehingga menjadi peluang bagi para investor dan berujung pada harga saham yang stabil. Variabel firm size $\left(\mathrm{X}_{2}\right)$ berpengaruh negatif sebesar 2,271 namun tidak signifikan terhadap stock price volatility, ini mengkonfirmasikan bahwa semakin besar firm size maka lebih rendah terjadinya stock price volatility dimana harga saham pada perusahaan yang besar lebih stabil dari pada harga saham pada perusahaan kecil karena pada perusahaan besar cenderung lebih di versivikasi. Variabel deviden payout $\left(\mathrm{X}_{3}\right)$ berpengaruh negatif sebesar 3,856 dan tidak signifikan terhadap stock price volatility, ini menunjukkan bahwa semakin besar dividend payout ratio maka semakin kecil stock price volatility dan begitu juga sebaliknya, dikarenakan perusahaan dengan kebijakan dividennya pasti akan menekan risiko perusahaan

Hasil penelitian ini memberikan implikasi bagi para investor di pasar modal dapat memperhatikan memperhatikan faktor-faktor yang mempengaruhi stock price volatility. berdasarkan hasil penelitian ini membuktikan bahwa tindakan yang di ambil manajemen perusahaan dalam memposisikan asset dan kewajiban perusahaan maupun pembagian deviden dapat memberikan pandangan bagi investor tentang bagaimana prospek perusahaan di masa yang akan datang dalam rangka pengambilan keputusan bagi investor. .

Penelitian ini diharapkan dapat memberikan kontribusi positif bagi semua pihak khususnya pihak investor dalam berinvestasi di pasar modal tetap memperhatikan tingkat leverage, firm size dan dividend payout ratio perusahaan yang akan diinvestasikan.

\section{DAFTAR PUSTAKA}

Bahreini,Vahid., Mehdi Baghbani dan Rezvan Bahreini. (2013). Analysis between financial leverage with the stock price and the operational performance of the accepted companies in Tehran's stock market. European Online Journal of Natural and Social Sciences 2013. Vol.2, No. 3

Dewi, S., \& Paramita, R. A. S. (2019). Pengaruh Kebijakan Dividen, Volume Perdagangan, Earning Volatility, Leverage, dan Firm Size 
Terhadap Volatilitas Harga Saham Perusahaan LQ45. Jurnal Ilmu Manajemen, 7(3), 761-771.

Griffin, W. R., dan Moorhead, G. (2010). Organizational Behavior managing peopleand organizations. USA. South-Western

Profilet, K. A., \& F. W. Bacon. (2013). Dividend Policy and Stock Price Volatility in The U.S. Equity Capital Market. Journal of Business and BehavioralSciences, 25 (2): 63-72

Ilaboya, O. J., Aggreh, M. (2013). Dividend Policy and Share Price Volatility. Journal of Asian Development, 2(2), 109-122.

Kartika, Andi 2010, Pengaruh Komitmen Organisasi Dan Ketidakpastian Lingkungan dalam Hubungan Antara Partisipasi Anggaran dengan Senjangan Anggaran (Studi Empirik Pada Rumah Sakit Swasta di Kota Semarang), Jurnal Akuntansi, Februari Hal, 39-60 ISSN 1979-4886

Sjahrial, Dermawan, 2009. Manajemen Keuangan, edisi 3. Jakarta: MitraWacana Media.

Suwito, Edy dan Arleen Herawaty. 2005. "Analisis Pengaruh Karakteristik Perusahaan terhadap Tindakan Perataan Laba yang dilakukan oleh Perusahaan yang Terdaftar di Bursa Efek Jakarta". Simposium NasionalAkuntansi VIII Solo. 15-16 September.

Seftianne dan Handayani. (2011). Faktor-faktor yang Mempengaruhi Struktur Modal Pada Perusahaan Publik Sektor Manufaktur. Jurnal Bisnis dan Akuntansi. Vol.13,No. 1, April 2011, Hlm. 39-56

Oktavianti, Santi, 2015. Pengaruh Ukuran Perusahaan, Modal Kerja, Arus Kas Terhadap Likuiditas (Studi Pada Perusahaan Manufaktur Sektor Industri Barang Konsumsi Yang Terdaftar Di Bursa Efek Indonesia Periode 2009-2013). Final Assignment (Bachelor and Vocational Degree), Universitas Widyatama

Rudianto, 2012, Pengantar Akuntansi Konsep \& Teknik Penyusunan Laporan Keuangan, Penerbit : Erlangga, Jakarta

Gumanti, Tatang Ary. 2013. Kebijakan Dividen Teori, Empiris, dan Implikasi. Jakarta: UPP STIM YKPN. 